\title{
Serological Investigation of Corynebacterium Pseudotuberculosis Infection in Sheep - Correlation between the Hemolysis Inhibition Test and the ELISA Test
}

Corynebacterium pseudotuberculosis causes caseous lymphadenitis in sheep and goats. The animals may be infected without showing clinical symptoms. Several serotests have therefore been employed to detect infected animals. Shen et al. (1982) performed an enzyme linked immunosorbent assay (ELISA) to detect antibodies against the organism using cell wall antigens. Maki et al. (1985) found that the toxin of the bacterium was a better antigen for assessing infection in the ELISA test. They reported that the antitoxin ELISA appeared to be as sensitive as the antihemolysin inhibition test (Zakl 1968).

The purpose of the present investigation was to study the correlation between the hemolysis inhibition test (HIT) and the ELISA test using C. pseudotuberculosis toxin as antigen. Sera from 52 sheep were examined for antibodies. HIT was performed in a similar way as described by Holstad (1986). Titre values (T) $\geq 0.6$ were regarded as positives.

A C. pseudotuberculosis strain (NVH 2586*) isolated from goat was used for the development of the ELISA test. This strain was grown in brain heart infusion broth (Difco Laboratories, Detroit, Michigan, USA). After static incubation at $30^{\circ} \mathrm{C}$ for 7 days, the culture was centrifuged and the supernatant subsequently filtered to remove all cells. The antigen used was an ammonium

*) Culture Collection at the Department of Microbiology and Immunology, Norwegian College of Veterinary Medicine. sulphate precipitate of the supernatant. The ELISA test was performed in a 4 layer system, the conjugate used being an alkaline phosphatase-conjugated goat antirabbit IgG diluted 1/10 000 in PBS Tween 20 containing $1 \%$ normal goat serum. The substrate was a solution containing $0.5 \mathrm{mg}$ p-nitrophenyl phosphate (Sigma, St. Louis, Missouri, USA) in $1 \mathrm{ml}$ diethanolamine buffer, $\mathrm{pH} 9,8$. The toxin was diluted in phosphatebuffered saline pH 7.2 (PBS) to a strength of 10 minimum hemolytic doses $/ \mathrm{ml}$, and then dispensed in $100 \mu \mathrm{l}$ aliquots into flatbottomed polystyrene microtitre plates (Nunc, Copenhagen, Denmark). After the plates were incubated at $4^{\circ} \mathrm{C}$ overnight, excess antigen was removed by washing 5 times in PBS containing $0.05 \%$ Tween 20 (PBS Tween-20). The plates were dried before test serum $(100 \mu \mathrm{l})$ prediluted $1 / 250$ in PBS Tween-20 was added to individual wells. PBS was used in control wells. The serum was allowed to react for $2 \mathrm{~h}$ at $37^{\circ} \mathrm{C}$, after which the plates were washed. Rabbit antisheep IgG (Nordic Immunology, Tilburg, Netherlands) $(100 \mu \mathrm{l})$, diluted $1 / 10,000$ in PBS Tween-20 containing $1 \%$ normal goat serum, was then added. After incubation for $2 \mathrm{~h}$ at $37^{\circ} \mathrm{C}$, plates were washed and the conjugate $(100 \mu \mathrm{l})$ added. The plates were incubated at $37^{\circ} \mathrm{C}$ for $2 \mathrm{~h}$ and washed. Substrate $(100 \mu \mathrm{l})$ was added and allowed to react for $5 \mathrm{~min}$. The reaction was stopped by the addition of $50 \mu \mathrm{l}$ of $4 \mathrm{~N}$ sodium hydroxide solution to each well. Optical density (OD) of the yellow colour was 


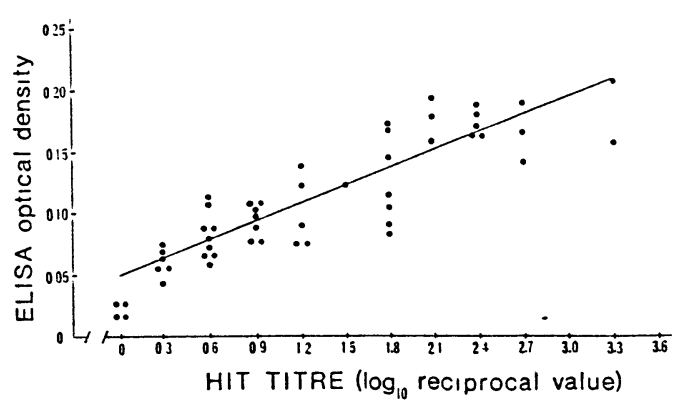

Figure 1. Comparison between the hemolysis inhibition test (HIT) response (titre) and the ELISA test response (optical density) for $C$ pseudotuberculosis antibodies in sera from 52 sheep. $y=0.05+0.05 x$.

read at $405 \mathrm{~nm}$ using a Multiskan ELISA reader (Titertex, Flow Laboratories, Helsinki, Finland), and blank adjustments were made against the control wells.

The results are presented in Fig. 1. Altogether 42 animals were positive in HIT. When the threshold value between positive and negative $O D$ was chosen as OD $\geq 0.0375,48$ animals were positive in the ELISA test. The correlation between the HIT and ELISA was highly significant $(r=$ $0,86, p<0.001$ ). Generally, sera with low OD values had low HIT-titres, while sera with high OD values also had high HITtitres. The HIT, which is easy to perform, is a sensitive test that correlates well with the actual infection in goats (Holstad 1986). The antitoxin ELISA is also easy to operate and gives results comparable with those in HIT.
The antigen used does not need to be purified (Maki et al. 1985). Since the ELISA test has a much higher capacity than HIT, it can effectively replace the latter, especially in screening for $C$ pseudotuberculosis infection.

\section{Acknowledgement}

We thank Johan Krogsrud and Trude Bakke for providing sera for the investigation.

\section{$J K N$ Kurla and $G$ Holstad}

Department of Microbiology and Immunology,

Norwegian College of Veternary Medicine, Oslo, Norway and

Department of Veterinary Pathology and

Microbiology, Faculty of Veterinary Medicine, Unıversity of Nairobi, Kenya.

\section{References}

Holstad $G$ Corynebacterium pseudotuberculosis infection in goats. I. Evaluation of two serological diagnostic tests. Acta vet. scand. 1986, 27, 575-583.

Makı LR, Shen SH, Bergstrom RC, Stetzenbach $L D$ Diagnosis of Corynebacterium pseudotuberculosis infections in sheep, using an enzyme-linked immunosorbent assay. Amer. J. vet. Res. 1985, 46, 212-214.

Shen $D T$, Jen $L W$, Gorham JR The detection of Corynebacterium pseudotuberculosis ant1body in goats by the Enzyme-Linked Immunosorbent Assay (ELISA). Proc. 3rd. Int. Conf. Goat Prod. Dis. Tucson, Arizona 1982, pp. 445-448.

Zakl MM The application of a new technique for diagnosis Corynebacterium ovis infection. Res. Vet. Sci. 1968, 9, 489-493.

\section{(Recelved October 5, 1988, accepted February 13, 1989)}

Reprints may be requested from: Gudmund Holstad, Department of Microbiology and Immunology, Norwegian College of Veterinary Medicine, P. O. Box 8146, Oslo Dep., N-0033 Oslo 1, Norway. 